\title{
Effect of S-adenosylmethionine on liver regeneration induced by partial hepatectomy
}

\author{
Lukáš Kohoutek ${ }^{1,2}$, Zuzana Červinková1, Otto Kučera ${ }^{1}$, Tomáš Roušar ${ }^{1}$, Tomáš Garnol ${ }^{1}$, \\ Jiř́i Šiller ${ }^{2}$ and Halka Lotková ${ }^{1}$ \\ ${ }^{1}$ Department of Physiology, Faculty of Medicine in Hradec Králové, Charles University in Prague, Šimkova 870, \\ 50038 Hradec Králové, Czech Republic \\ ${ }^{2}$ Department of Surgery, Faculty of Health Studies, University of Pardubice, Prümyslová 395, 53210 Pardubice, \\ Czech Republic
}

\begin{abstract}
S-adenosylmethionine (SAMe) is a key metabolite regulating growth, differentiation and death of hepatocytes. Experimentally, exogenous SAMe has been documented to attenuate hepatocarcinogenesis. The aim of our study was to evaluate the effect of SAMe on proliferation of hepatocytes that are not cancerously transformed.

Partial 2/3 hepatectomy $(\mathrm{PH})$ was performed in rats, control animals underwent laparotomy. SAMe was injected immediately after the surgery and then at $24 \mathrm{~h}$ intervals for two days at $10 \mathrm{or} 40 \mathrm{mg} / \mathrm{kg}$. The animals were sacrificed 24,48 and $72 \mathrm{~h}$ after operation and the intensity of liver regeneration was evaluated. SAMe treatment at $10 \mathrm{mg} / \mathrm{kg}$ was associated with decrease in the synthesis of liver DNA $48 \mathrm{~h}$ after PH, however, it was not reflected in DNA content. SAMe treatment at $40 \mathrm{mg} / \mathrm{kg}$ led to the reduction of DNA synthesis $72 \mathrm{~h}$ after PH followed by the diminution of DNA content. The results have documented the inhibition of the liver regeneration by SAMe that may be mediated by the suppression of liver fat accumulation. Cell GSH level correlating with the growth rate was not affected by SAMe. Prevention from the decrease in the intracellular content of SAMe, as a factor attenuating regeneration remains to be verified.
\end{abstract}

Key words: Partial hepatectomy — Liver regeneration — S-adenosylmethionine

\begin{abstract}
Abbreviations: ALT, alanine aminotransferase; AST, aspartate aminotransferase; GSH, glutathione; MAT, methionine adenosyltransferase; NF- $\kappa \mathrm{B}$, nuclear factor- $\kappa \mathrm{B}$; PEMT, phosphatidylethanolamine methyltransferase; $\mathrm{PH}$, partial hepatectomy; SAMe, S-adenosylmethionine; TAG, triacylglycerols; TNFa, tumor necrosis factor $\alpha$; ROS, reactive oxygen species; VLDL, very low density lipoproteins.
\end{abstract}

\section{Introduction}

$\mathrm{S}$-adenosylmethionine (SAMe) is a naturally occurring substance produced from methionine and adenosine triphosphate in reaction catalyzed by methionine adenosyltransferase (MAT) in the cytosol of almost all mammalian cells, however liver is the major site of its synthesis and utilization (Mato et al. 1997). SAMe has been demonstrated to protect hepatocytes from damage induced in experimental models by hepatotoxins $(\mathrm{Wu}$

Correspondence to: Halka Lotková, Department of Physiology, Faculty of Medicine in Hradec Králové, Charles University in Prague, Šimkova 870, 50038 Hradec Králové, Czech Republic E-mail: lotko@lfhk.cuni.cz et al. 1996; Valentovic et al. 2004; Lotková et al. 2005; Kučera et al. 2006; Lotková et al. 2007) or accompanying human chronic liver diseases (Frezza et al. 1990; Manzillo et al. 1992). Recently, SAMe is mainly considered a key compound regulating proliferation, differentiation and cell death (Lu and Mato 2008). There is growing evidence that SAMe administration inhibits growth of human or experimentally induced hepatocellular carcinoma (Cai et al. 1998) and attenuates the development of preneoplastic cells (Pascale et al. 1995, 2002) thus making SAMe an attractive agent for chemoprevention and treatment of hepatocellular carcinoma. The aim of our study was to evaluate the effect of SAMe treatment on the intensity of liver regeneration (the growth of cells that are not cancerously transformed) with respect to the dose of SAMe. 


\section{Materials and Methods}

\section{Animal experiments}

Male albino Wistar rats (BioTest, Konárovice, Czech Republic) were housed at $23 \pm 1{ }^{\circ} \mathrm{C}, 55 \pm 10 \%$ relative humidity, air exchange $12-14$ times/h, and 12-h light/dark cycle periods (6:00 a.m. to 6:00 p.m.). The animals had free access to standard laboratory rat chow (DOS 2B, Velaz, Czech Republic) and tap water. All animals received care according to the guidelines set by the institutional Animal Use and Care Committee of the Charles University, Prague, Czech Republic.

Partial hepatectomy ( $\mathrm{PH}$ - removal of $65-70 \%$ of liver tissue) was performed under ether anesthesia according to Higgins and Anderson (1931). In sham-operated rats median laparotomy and mobilization of the liver were carried out. SAMe (Transmetil, Abbott, Czech Republic) was injected i.m. immediately after the operation and then at $24 \mathrm{~h}$ intervals for two days at the doses of 10 and $40 \mathrm{mg} / \mathrm{kg}$. Control animals received i.m. injection of an equal amount of saline. The animals were sacrificed 24,48 and $72 \mathrm{~h}$ after operation by exsanguination from abdominal aorta. The blood was collected for biochemical assays and livers were removed immediately.

\section{Biochemical analysis}

Plasma levels of alanine aminotransferase (ALT), and aspartate aminotransferase (AST) were determined using commercial sets Roche (Basel, Switzerland) and performed with an analyser Modular (Roche; Basel, Switzerland).

Liver triacylglycerol content was determined by slightly modified method according to Jover (1963).
For estimation of liver DNA synthesis, the rats were labeled by an i.v. injection of ${ }^{3} \mathrm{H}$-thymidine $(200 \mu \mathrm{Ci} / \mathrm{kg}$ b.w. one hour before sampling). The radioactivity of livers was measured according to Short et al. (1969) using LS 6 000LL scintillation counter (Beckman Instruments, Fullerton, Ca, USA). Liver DNA concentrations were determined by the diphenylamine reaction (Burton 1956) from which the specific DNA activity was calculated.

Liver homogenates were used for the analysis of reduced glutathione (GSH) by reverse-phase high-performance liquid chromatography (Shimadzu, Japan) using the method of Hissin and Hilf (1976) that was slightly modified (Kandár et al. 2007). The reverse-phase column Discovery C18, $15 \mathrm{~cm} \times$ $4 \mathrm{~mm}$ ID, $5 \mu \mathrm{m}$ particles (Supelco, USA), served for separation. Fluorometric detection (excitation wavelength 350 $\mathrm{nm}$, emission wavelength $420 \mathrm{~nm}$ ) followed a postcolumn derivatization reaction with o-phthalaldehyde. The CSW32 programme (DataApex, Czech Republic) was used for collecting and processing of the chromatographic data.

\section{Statistical analysis}

All values are expressed as means \pm SD. One-way ANOVA test was used to determine the statistical significance. TukeyKramer's post hoc test was used for multiple comparisons between groups (GraphPad Instant 3.06 for Windows, GraphPad Software, CA, USA).

\section{Results}

\section{Serum ALT and AST activities}

$24 \mathrm{~h}$ after PH, ALT activity in the serum was rised (Fig. 1) as compared to control $(p<0.05)$. Then, ALT activity de-

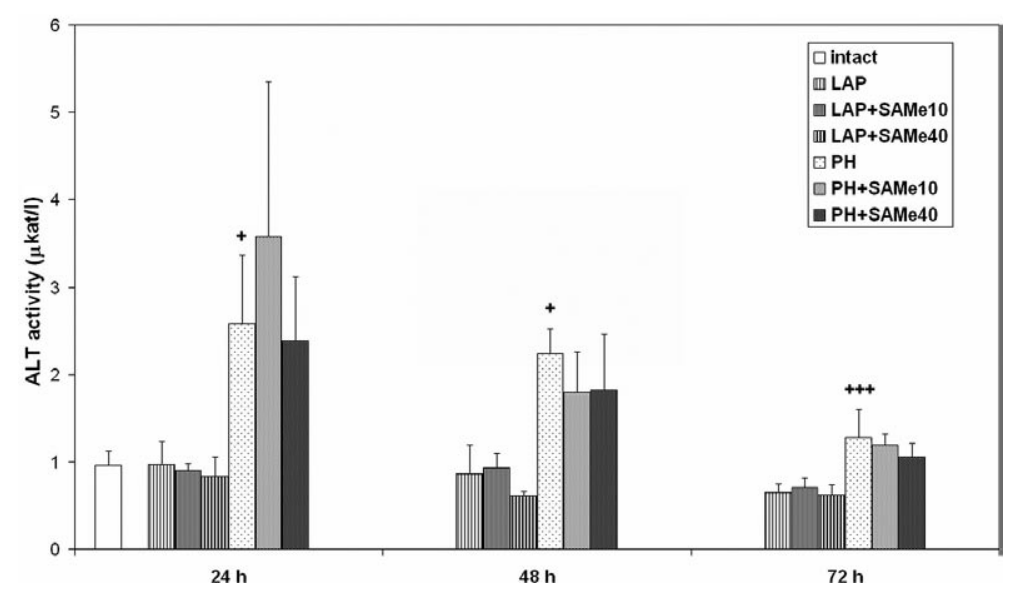

Figure 1. ALT activity in the serum 24,48 and $72 \mathrm{~h}$ after operation: in intact animals, after laparotomy (LAP), after laparotomy and treatment with SAMe at $10 \mathrm{mg} / \mathrm{kg}$ (LAP+SAMe10), after laparotomy and treatment with SAMe at $40 \mathrm{mg} / \mathrm{kg}$ (LAP+SAMe40), after PH, after PH and treatment with SAMe at $10 \mathrm{mg} / \mathrm{kg}(\mathrm{PH}+\mathrm{SAMe} 10)$, after PH and treatment with SAMe at $40 \mathrm{mg} / \mathrm{kg}(\mathrm{PH}+\mathrm{SAMe} 40) .{ }^{+} p<0.05,{ }^{+++} p<0.001 v$ s. LAP. 


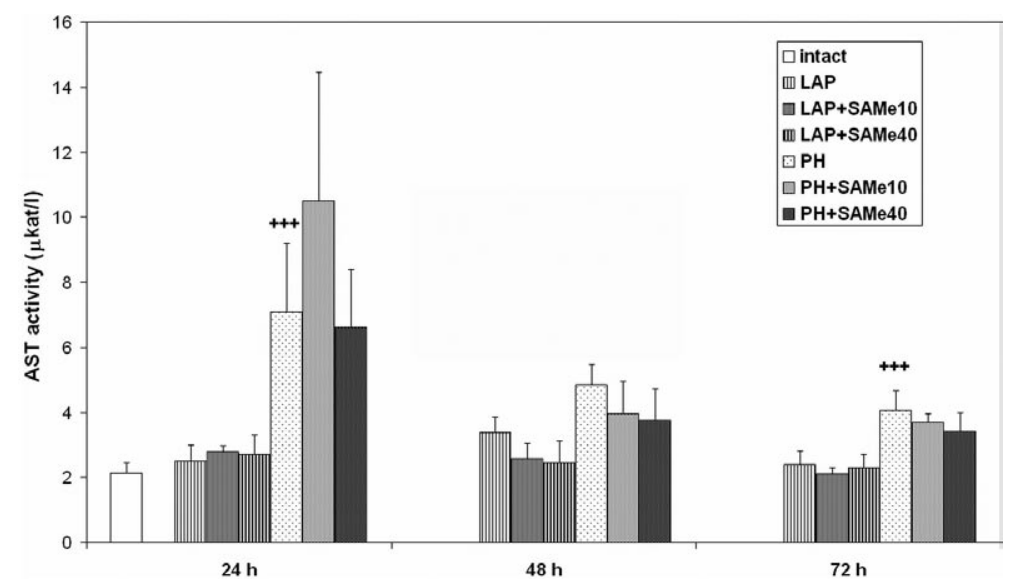

Figure 2. AST activity in the serum 24,48 and $72 \mathrm{~h}$ after operation: see legend for Fig. $1 .{ }^{+++} p<0.001 v s$. LAP.

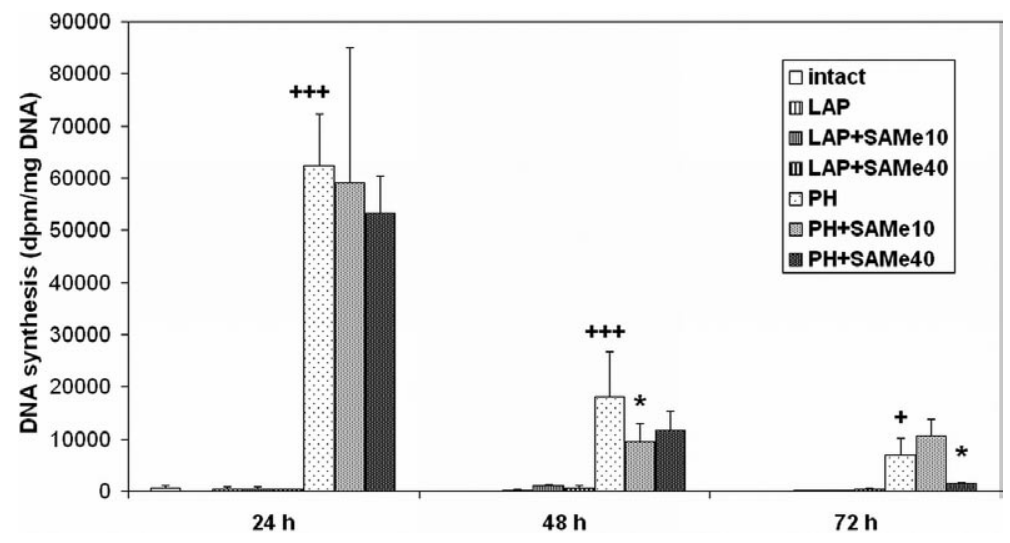

Figure 3. DNA synthesis in the liver 24,48 and $72 \mathrm{~h}$ after operation; see legend for Fig. $1 .{ }^{+} p<0.05,{ }^{+++} p<0.001 v s$. LAP, ${ }^{\star} p<0.05 v s$. PH.

clined continuously, nevertheless it sustained at $48 \mathrm{~h}(p<$ $0.05)$ and $72 \mathrm{~h}(p<0.001)$ significantly higher compared to sham-operated group. SAMe treatment did not influence this ALT activity.

Fig. 2 documents AST activity in the serum. Analogous to the development of ALT activity, $24 \mathrm{~h}$ after $\mathrm{PH}$ the activity of AST rised as compared to control $(p<0.001)$ and then declined. SAMe treatment did not change AST activity.

\section{Liver DNA synthesis}

Fig. 3 demonstrates low DNA synthesis in the liver of sham-operated rats. $24 \mathrm{~h}$ after $\mathrm{PH}$, liver DNA synthesis was significantly higher as compared to sham-operated rats $(p<0.001)$. Then, DNA synthesis lowered, neverheless the values persisted significantly higher at $48 \mathrm{~h}(p<$ $0.001)$ and $72 \mathrm{~h}(p<0.05)$. SAMe treatment at $10 \mathrm{mg} / \mathrm{kg}$ was accompanied with decrease in DNA sythesis $48 \mathrm{~h}$ after $\mathrm{PH}$ as compared to animals with $\mathrm{PH}$ that were untreated $(p<0.05)$. This decline did not continue as determined $72 \mathrm{~h}$ after surgery in contrast to the untreated group. SAMe at the dose of $40 \mathrm{mg} / \mathrm{kg}$ led to decrease in DNA synthesis $72 \mathrm{~h}$ after $\mathrm{PH}(p<0.05)$.

\section{Liver DNA content}

$24 \mathrm{~h}$ after $\mathrm{PH}$, the liver DNA content was significantly lower (Fig. $4 ; p<0.001$ ) in hepatectomized group compared to the controls. Then, DNA content rised gradually, nevertheless the values were always sidnificantly lower as compared to controls $(p<0.001)$. SAMe treatment at $10 \mathrm{mg} / \mathrm{kg}$ in sham-operated rats caused after both the 48and 72-h intervals significant decrease in DNA content as compared to untreated controls (0.001). This effect was not observed in hepatectomized group. SAMe treatment with $40 \mathrm{mg} / \mathrm{kg}$ was accompanied with lower DNA content $72 \mathrm{~h}$ after $\mathrm{PH}$ compared to untreated hepatectomized rats $(p<0.05)$. 


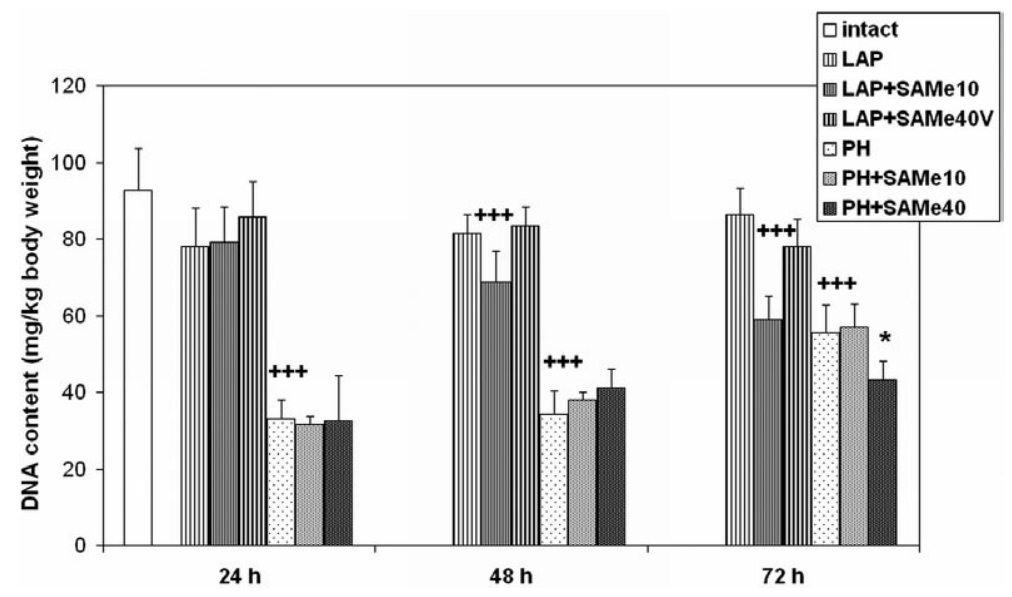

Figure 4. DNA content in the liver 24,48 and $72 \mathrm{~h}$ after operation; see legend for Fig. $1 .{ }^{+++} p<0.001 v s . \mathrm{LAP},{ }^{\star} p<0.05 v s . \mathrm{PH}$.

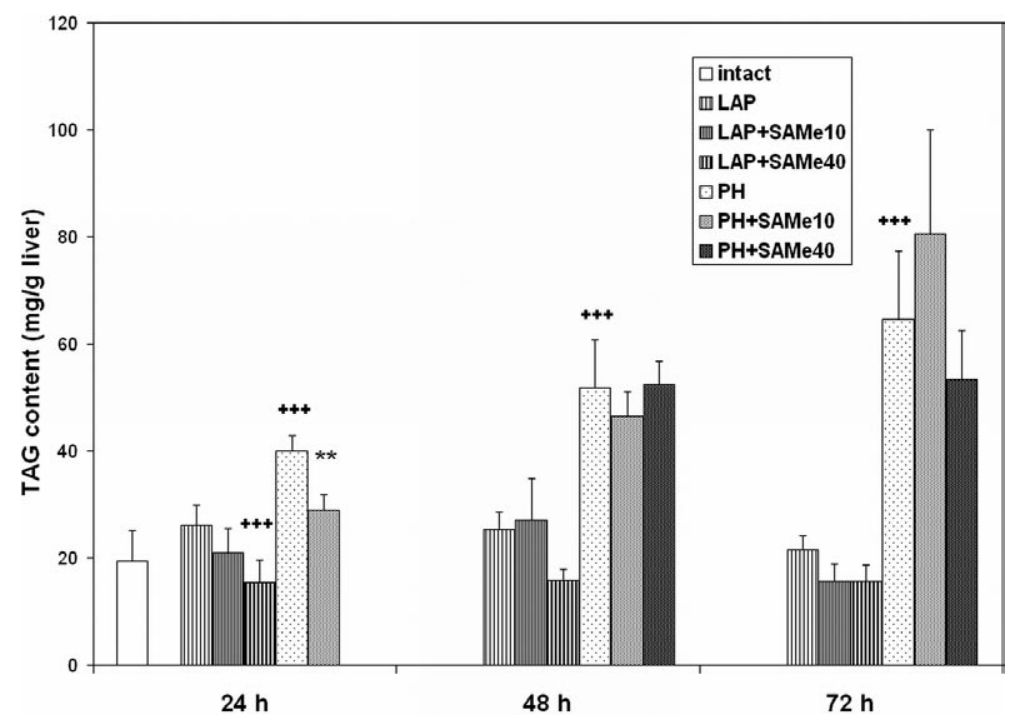

Figure 5. TAG content in the liver 24,48 and $72 \mathrm{~h}$ after operation; see legend for Fig. $1 .{ }^{+++} p<0.001 v s . \mathrm{LAP},{ }^{* *} p<0.01 v s . \mathrm{PH}$.

\section{Liver triacylglycerols (TAG) content}

$\mathrm{PH}$ induced a continuous rise in the liver TAG content compared to sham-operated group $(p<0.001)-$ Fig. 5. SAMe treatment at $10 \mathrm{mg} / \mathrm{kg}$ alleviated this increase $24 \mathrm{~h}$ after $\mathrm{PH}$ as compared to untreated hepatectomized group $(p<0.01)$. Contrary to untreated controls, lower TAG content was also determined $24 \mathrm{~h}$ after laparotomy and treatment with SAMe at $40 \mathrm{mg} / \mathrm{kg}(p<0.001)$.

\section{Liver GSH content}

$48 \mathrm{~h}$ after $\mathrm{PH}$, a significant rise of reduced form of GSH was observed compared to sham-operated animals $(p<$ $0.001)$. Fig. 6 documents, SAMe treatment $(40 \mathrm{mg} / \mathrm{kg})$ after laparotomy was accompanied with decrease in reduced GSH compared to untreated group $(p<0.01)$.

\section{Discussion}

The majority of hepatocytes in the liver of adult vertebrates are resting in the $\mathrm{G}_{0}$ state of the cell cycle. In the early period of $0-5 \mathrm{~h}$ after $\mathrm{PH}$ called priming; hepatocytes enter from quiescence to the $G_{1}$ phase of the cell cycle before they can fully respond to growth factors. Within $30 \mathrm{~min}$ after $\mathrm{PH}$, preexisting transcription factors are activated and subsequently they trigger the transcription of immediate-early genes encoding proteins that regulate later phases in $G_{1}$ (Taub 1996; Fausto 2000; Michalopoulos 2008). Activation 


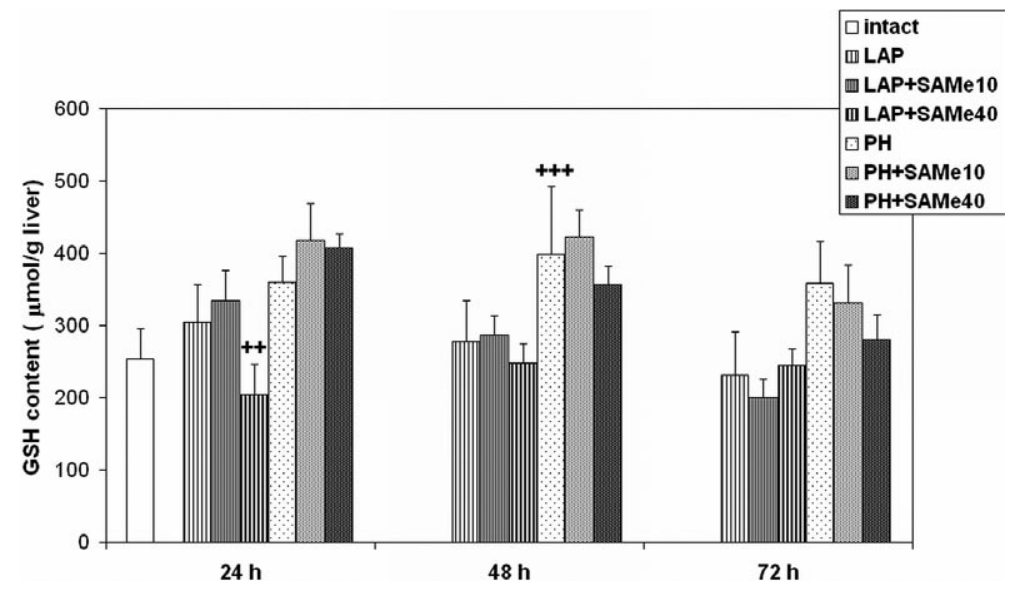

Figure 6. GSH content in the liver 24,48 and $72 \mathrm{~h}$ after operation; see legend for Fig. $1 .{ }^{++} p<0.01,{ }^{+++} p<0.001 v s$. LAP.

of the relevant transcription factor nuclear factor- $\kappa ß$ (NF$\kappa ß)$ is mediated by tumor necrosis factor $\alpha(\mathrm{TNF} \alpha)$ signaling pathway (Fausto 2000) that generates an excess of reactive oxygen species (ROS). The excess ROS is dissipated during a few hours of the regenerative response through the action of GSH and other thiols. The finding of Huang et al. (1998) showes that GSH level is doubled at $12 \mathrm{~h}$ and remains elevated at $24 \mathrm{~h}$ after $\mathrm{PH}$. Preventing this increase in liver GSH leads to the inhibition of DNA synthesis (Huang et al. 2001). The requirement for increased GSH prior to DNA synthesis can be related to the activity of the rate-limiting enzyme in DNA synthesis ribonucleotide reductase (Holmgren 1981). A range of studies have documented exogenous SAMe as a hepatoprotective substance exerting its beneficial effects by different pathways. At a cellular level SAMe acts as a methyl group donor in many transmethylation reactions, including the methylation of phospholipids within the cell membranes whereby plasma membrane fluidity is restored. The transsulfuration pathway of SAMe metabolism is important for biosynthesis of GSH. The addition of SAMe was documented to increase GSH levels in carbon tetrachloride-treated rats (Gassó et al. 1996), in hepatocytes cultured both with Dgalactosamine (Wu et al. 1996) and GSH-depleting drugs (Ponsoda et al. 1991). We assumed that SAMe treatment could lead to the increase in GSH synthesis thus affecting the intensity of DNA synthesis. For clinical application, the doses of SAMe from 5 to $12 \mathrm{mg} / \mathrm{kg}$ are recommended. In our study, SAMe was used after PH and laparotomy, respectively, at dose either 10 or $40 \mathrm{mg} / \mathrm{kg}$. In accordance with other authors, our results demonstrate the increase in GSH content in the liver of hepatectomized rats. Nevertheless, SAMe treatment in both doses did not change the GSH content. Similarly, the increase in GSH content was not observed after hepatectomy in rats that were pretreated with SAMe at 10 mg/kg (Fernández et al. 2003).
Liver regeneration was estimated 24, 48 a $72 \mathrm{~h}$ after $\mathrm{PH}$ by the measurement of DNA synthesis and DNA content in the liver. PH induced a dramatic increase in DNA synthesis peaked at $24 \mathrm{~h}$ after surgery. Even though, DNA content was lower as a consequence of $\mathrm{PH}$, it raised during $72 \mathrm{~h}$ after surgery. SAMe treatment at dose $10 \mathrm{mg} / \mathrm{kg}$ was associated with attenuation of DNA synthesis that was not followed by a reduction of DNA content in the liver. Nevertheless, SAMe treatment with $40 \mathrm{mg} / \mathrm{kg}$ was accompanied by both attenuation of DNA synthesis and decrease in DNA content in the liver. In parallel with the early regenerative events the liver accumulates large amounts of TAG fat (Murray et al. 1981). In our study, a significant augmentation of TAG content was registered $24 \mathrm{~h}$ after $\mathrm{PH}$. Further, the steatosis intensified at 48- and 72-h intervals. SAMe treatment diminished fat accumulation in the liver $24 \mathrm{~h}$ after $\mathrm{PH}$. Unfortunately, this effect of SAMe could be measured only at lower dose because of technical occasion. We can presume SAMe to affect liver steatosis at higher dose with respect to that this dose of SAMe led to the restriction of liver TAG even after laparotomy. Although mechanism responsible for liver steatosis and its functional importance during liver regeneration remain unclear, anyhow hepatocellular fat accumulation has been registered to be essential for normal liver regeneration (Shteyer et al. 2004). This can be supported by finding that proliferation of primary hepatocytes in cell culture is associated with marked intracellular accumulation of fat (Michalopoulos et al. 1982). First two days after major hepatectomy, the remnant liver is mainly dependent upon the oxidation of fatty acids giving evidence for the significance of fat accumulation in the liver (Simek and Sedlácek 1965; Nakatani et al. 1981). Moreover, enteral feeding with medium-chain TAG and long-chain TAG supplement actually preserved liver regeneration (Červinková et al. 1995; Bláha et al. 1999). Our current results indicate the inhibitory effect of SAMe on liver fat accumulation induced by 
PH. Mechamisms by which SAMe can attenuate fat accumulation in hepatocytes have been studied using ethanol-induced steatosis. SAMe supplementation attenuated the ethanol-induced rise of TAG in cultured hepatocytes (Kharbanda et al. 2005) that was accompanied with the prevention of decrease in the activity of SAMe-dependent methyltransferase (phosphatidylethanolamine methyltransferase; PEMT). PEMT was shown to play an important role in the synthesis and secretion of very low density lipoproteins (VLDL) in hepatocytes (Noga et al. 2002; Zhu et al. 2003). In micropigs, supplementing ethanol diets with SAMe reduced liver triacylglycerol levels by upregulation of adiponectin-mediated pathways and decreased fatty acid and TAG synthesis (Esfandiari et al. 2007).

Not only the effects of SAMe resulting from its metabolism but also an intracellular concentration of SAMe itself can affect the growth of cells. In hepatocytes, SAMe levels are related to the differentiation status, being high in quiescent and low in proliferating cells (Cai et al. 1998; Lu and Mato 2008). Three isoforms of MAT (MAT I, MAT II, MAT III) have been identified in mammalian tissues. Under normal conditions, MAT I/III are the main isoforms present in the liver. MAT I and III are encoded by the gene MAT1A that is expressed only in the adult liver (Gil et al. 1996). The expression of the widely distributed gene MAT2A that encodes MAT II is associated with liver cell growth. SAMe level falls early in the course of liver regeneration and reaches its lowest level around 12 to $24 \mathrm{~h}$ after $\mathrm{PH}$ in rats. This fall in SAMe content coincides with increased expression of MAT2A (Huang et al. 1998). In cultured rat hepatocytes, MAT1A expression progressively decreases and MAT2A expression is induced. This switch in gene expression was prevented by adding SAMe to the culture medium (GarcíaTrevijano et al. 2000). SAMe treatment in rat hepatocyte culture also inhibited hepatocyte growth factor-induced cyclin D1 and D2 expression resulting in the inhibition of DNA synthesis (García-Trevijano et al. 2002). Then the addition of exogenous SAMe can prevent the regenerating liver from the fall in SAMe content (Pascale et al. 1995) that seems to be a crucial for progression of the cell cycle and hepatocyte growth.

We have confirmed the dose-dependent inhibitory effect of SAMe on liver regeneration that may be mediated by an attenuation of the fat accumulation in the liver. Intracellular GSH level correlating with growth rate was not affected by SAMe. Prevention of SAMe depletion in the liver as a factor attenuating regenerative response remains to be verified.

Acknowledgements. Supported by grant MSM 0021620820 and NS 9739-3/2008.

\section{References}

Bláha V., Cervinková Z., Simek J., Lotková H., Zadák Z. (1999): Long and medium chain triacylglycerols in nutritional support of liver regeneration of partially hepatectomized rats. Physiol. Res. 48, 457-463

Burton K. (1956): A study of the conditions and mechanism of the diphenylamine reaction for the colorimetric estimation of deoxyribonucleic acid. Biochem. J. 62, 315-323

Cai J., Mao Z., Hwang J. J., Lu S. C. (1998): Differential expression of methionine adenosyltransferase genes influences the rate of growth of human hepatocellular carcinoma cells. Cancer Res. 58, 1444-1450

Červinková Z., Lotková H., Bláha V., Zadák Z., Sýkorová L. (1995): Experimental possibilities of liver regeneration and clinical utilization for patient. Zdravotnické noviny: Lékařské listy 49, 1 (in Czech)

Esfandiari F., You M., Villanueva J. A., Wong D. H., French S. W., Halsted C. H. (2007): S-adenosylmethionine attenuates hepatic lipid synthesis in micropigs fed ethanol with a folate-deficient diet. Alcohol Clin. Exp. Res. 31, 12311239; doi:10.1111/j.1530-0277.2007.00407.x

Fausto N. (2000): Liver regeneration. J. Hepatol. 32, 19-31; doi:10.1016/S0168-8278(00)80412-2

Fernández L., Pérez V., Muñoz M., Corpa J. M., Abad M., Carbajo M. T. (2003): Effects of S-adenosylmethionine on hepatic regeneration after partial hepatectomy in the rat. J. Physiol. Biochem. 59, 63-4; doi:10.1007/BF03179869

Frezza M., Surrenti C., Manzillo G., Fiaccadori F., Bortolini M., Di Padova C. (1990): Oral S-adenosylmethionine in the symptomatic treatment of intrahepatic cholestasis. A double-blind, placebo-controlled study. Gastroenterology 99, 211-215

García-Trevijano E. R, Latasa M. U, Carretero M. V., Berasain C., Mato J. M., Avila M.A. (2000): S-adenosylmethionine regulates MAT1A and MAT2A gene expression in cultured rat hepatocytes: a new role for S-adenosylmethionine in the maintainance of the differentiated status of the liver. FASEB J. 14, 2511-2518; doi:10.1096/fj.00-0121com

García-Trevijano E. R., Martínez-Chantar M. L., Latasa M. U., Mato J. M., Avila M. A. (2002): NO sensitizes rat hepatocytes to proliferation by modifying S-adenosylmethionine levels. Gastroenterology 122, 1355-1363; doi:10.1053/ gast. 2002.33020

Gassó M., Rubio M., Varela G., Cabré M., Caballería J., Alonso E., Deulofem R., Camps J., Giménez A., Pajares M. Parés A., Mato J. M., Rodés J. (1996): Effects of S-adenosylmethionine on lipid peroxidation and liver fibrogenesis in carbon tetrachloride-induced cirrhosis. J. Hepatol. 25, 200-205; doi:10.1016/S0168-8278(96)80074-2

Gil B., Casado M., Pajares M. A., Boscá L., Mato J. M., Martín-Sanz P., Alvarez L. (1996): Differential expression pattern of S-adenosylmethionine synthetase isoenzymes during rat liver development. Hepatology 24, 876-881

Higgins G. M., Anderson R. M. (1931): Experimental pathology of the liver. I Restoration of the liver of the white rat following partial surgical removal. Arch. Pathol. 12, 186-202

Hissin P. J., Hilf R. (1976): A fluorometric method for determination of oxidized and reduced glutathione in tissues. Anal. Biochem. 74, 214-226; doi:10.1016/0003-2697(76)90326-2

Holmgren A. (1981): Regulation of ribonucletide reduktase. Curr. Top. Cell. Regul. 19, 47-76 
Huang Z. Z, Li H., Cai J., Kuhlenkamp J., Kaplowitz N., Lu S. C. (1998): Changes in glutathione homeostasis during liver regeneration in the rat. Hepatology 27, 147-153; doi:10.1002/hep.510270123

Huang Z. Z., Chen C., Zen Z., Yang H., Mao Z., Lu S. C. (2001): Mechanism and significance of increased glutathione level in human hepatocellular carcinoma and liver regeneration. FASEB J. 15, 19-21

Jover A. (1963): A technique for the determination of serum glycerides. J. Lipid Res. 4, 228

Kandár R., Záková P., Lotková H., Kucera O., Cervinková Z. (2007): Determination of reduced and oxidized glutathione in biological samples using liquid chromatography with fluorimetric detection. J. Pharm. Biomed. Anal. 43, 1382-1387; doi:10.1016/j.jpba.2006.11.028

Kharbanda K. K., Rogers D. D., Mailliard M. E., Siford G. L., Barak A. J., Beckenhauer H. C., Sorrell M. F., Tuma D. J. (2005): A comparison of the effects of betaine and $S$-adenosylmethionine on ethanol-induced changes in methionine metabolism and steatosis in rat hepatocytes. J. Nutr. 135, 519-524

Kucera O., Cervinková Z., Lotková H., Kriváková P., Rousar T., Muzáková V., Hézová R., Kandár R., Rudolf E. (2006): Protective effect of S-adenosylmethionine against galactosamine-induced injury of rat hepatocytes in primary culture. Physiol. Res. 55, 551-560

Lotková H., Cervinková Z., Kucera O., Kriváková P., Kandár R. (2005): Protective effect of S-adenosylmethionine on cellular and mitochondrial membranes of rat hepatocytes against tert-butylhydroperoxide-induced injury in primary culture. Chem. Biol. Interact. 156, 13-23, doi:10.1016/j.cbi.2005.06.008

Lotková H., Cervinková Z., Kucera O., Rousar T., Kriváková P. (2007): S-adenosylmethionine exerts a protective effect against thioacetamide-induced injury in primary cultures of rat hepatocytes. Altern. Lab. Anim. 35, 363-371

Lu S. C., Mato J. M. (2008): S-Adenosylmethionine in cell growth, apoptosis and liver cancer. J. Gastroenterol. Hepatol. 23 (Suppl. 1), S73-77; doi:10.1111/j.1440-1746.2007.05289.x

Manzillo G., Piccinino F., Surrenti C., Frezza M., Giudici G. A., Le Grazie C. (1992): Multicentre double-blind placebocontrolled study of intravenous and oral S-adenosylL-methionine (SAMe) in cholestatic patiens with liver disease. Drug Invest. 4 (Suppl. 4), 90-100

Mato J. M., Alvarez L., Ortiz P., Pajares M. A. (1997): S-Adenosylmethionine synthesis: molecular mechanisms and clinical implications. Pharmacol. Ther. 73, 265-280; doi:10.1016/ S0163-7258(96)00197-0

Michalopoulos G. K. (2008): Liver regeneration. J. Cell. Physiol. 213, 286-300; doi:10.1002/jcp.21172

Michalopoulos G. K., Cianciulli H. D., Novotny A. R., Kligerman A. D., Strom S. C., Jirtle R. L. (1982): Liver regeneration studies with rat hepatocytes in primary culture. Cancer Res. 42, 4673-4682

Murray A. B., Strecker W., Silz S. (1981): Ultrastructural changes in rat hepatocytes after partial hepatectomy, and comparison with biochemical results. J. Cell. Sci. 50, 433-448

Nakatani T., Ozawa K., Asano M., Ukikusa M., Kamiyama Y., Tobe T. (1981): Changes in predominant energy substrate after hepatectomy. Life Sci. 28, 257-264; doi:10.1016/00243205(81)90731-1

Noga A. A., Zhao Y., Vance D. E. (2002): An unspected requirement for phosphatidylethanolamine $\mathrm{N}$-methyltranferase in the secretion of very low density lipoproteins. J. Biol. Chem. 277, 42358-42365; doi:10.1074/jbc.M204542200

Pascale R. M., Simile M. M., De Miglio M. R., Nutrie A., Daino L., Seddain M. A., Rao P. M., Rajalakshmi S., Sarma D. S., Feo F. (1995): Chemoprevention by S-adenosyl-L-methionine of rat liver carcinogenesis initiated by 1,2-dimethylhydrazine and promoted by orotic acid. Carcinogenesis 16, 427-430; doi:10.1093/carcin/16.2.427

Pascale R. M., Simile M. M., De Miglio M. R., Feo F. (2002): Chemoprevention of hepatocarcinogenesis: S-adenosylL-methionine. Alcohol 27, 193-198; doi:10.1016/S07418329(02)00227-6

Ponsoda X., Jover R., Gómez-Lechón M. J., Fabra R., Trullenque R., Castell J. V. (1991): Intracellular glutathione in human hepatocytes incubated with S-adenosyl-L-methionine and GSH-depleting drugs. Toxicology 70, 293-302; doi:10.1016/0300-483X(91)90004-K

Short J., Zemel R., Kanta J., Lieberman I. (1969): Stimulation of deoxyribonucleic acid synthesis in the liver parenchymal cells of the intact rat. Nature 223, 956-957; doi:10.1038/ 223956a0

Shteyer E., Liao Y., Muglia L. J., Hruz P. W., Rudnick D. A. (2004): Disruption of hepatic adipogenesis is associated with impaired liver regeneration in mice. Hepatology 40, 1322-1332; doi:10.1002/hep.20462

Simek J., Sedlácek J. (1965): Effect of glucose administered in vivo or in vitro on the respiratory quotient of rat liver tissue after partial hepatectomy. Nature 207, 761-762; doi:10.1038/207761a0

Taub R. (1996): Liver regeneration 4: transcriptional control of liver regeneration. FASEB J. 10, 413-427

Valentovic M., Terneus M., Harmon R. C., Carpenter A. B. (2004): $\mathrm{S}$-Adenosylmethionine (SAMe) attenuates acetaminophen hepatotoxicity in C57BL/6 mice. Toxicol. Lett. 154, 165-174; doi:10.1016/j.toxlet.2004.07.010

Wu J., Söderbergh H., Karlsson K., Danielsson A. (1996): Protective effect of S-adenosyl-L-methionine on bromobenzeneand $\mathrm{D}$-galactosamine-induced toxicity to isolated rat hepatocytes. Hepatology 23, 359-365

Zhu X., Song J., Mar M. H., Edwards L. J., Zeisel S. H. (2003): Phosphatidylethanolamine N-methyltranferase (PEMT) knockout mice have hepatic steatosis and abnormal hepatic choline metabolite concentrations despite ingesting a recommended dietary intake of choline. Biochem. J. 370, 987-993; doi:10.1042/BJ20021523

Received: July 6, 2009

Final version accepted: October 8, 2009 